\title{
A FEW NOTES ON THE BOTANY OF LORD HOWE ISLAND.
}

\author{
(Sixth paper.*)
}

By J. H. Maiden, I.S.O., F.R.S., F.L.S., Government Botanist and Director of the Botanic Gardens, Sydney.

Since the publication of my last paper, the following have appeared:-

1. "A revised list of Norfolk Island flora, with some notes on the species," by Robert M. Laing. Trans. N.Z. Inst., xlvii., 1915.

2. "The vegetation and flora of Lord Howe Island," by W. R. B. Oliver, Trans. N.Z. Inst., xlix, 1917, 94. Free access was given Mr. Oliver to the Lord Howe and Norfolk Islands collections in the National Herbarium, Sydney, when he was preparing his paper.

Mr. J. L. Boorman paid a visit to Lord Howe Island from February to April of the present year, on business of the Board of Control of the Island, and took the opportunity of making botanical collections for the National Herbarium, Sydney.

The vast majority of the plants he brought have already been recorded, but the following presumably indigenous species are believed to be new records:-

1. Malvastrum tricuspidatum A. Gray. 2. Erythraea australis R.Br.

I am aware that there may be a difference of opinion as to whether they are truly indigenous; judging from observations in regard to the Norfolk Island flora (see Laing).

He collected Mesembryanthemum australe Sol., recorded by Oliver, p. 137; also Kyllinga monocephala Rottb. (Oliver, p. 128).

Messrs. H. T. Wilson and E. King brought specimens of Adiantum formosum R.Br. (name confirmed by Mr. T. Whitelegge) from the south-yest slope of the Island, locally known as the "Little Slope," near the salt water. "Grows $2 \mathrm{ft}$. 6 inches, and very strong, and not noticed before." This fern does not appear to have been previously recorded from the Island.

$\mathrm{Mr}$. Boorman brought specimens of a variegated Palm, and in view of the fact that variegation is not a common character in the Family, it is worthy of record. The plant is Howea Forsteriana Bece., and a pleasing parallel variegation extends throughout the plant, affecting both rachises and leaflets. The tree (the only one on the Island), is about 30 feet high,. and probably 30 or 40 years of age. It is growing at Erskine Valley, near the Burnt Hut.

•Previous reference, These Proceedings, xxxix., 1914, p.377. 
Oliver (p. 129) draws attention to Hybrids of Howea. I have had some of these plants under observation since 1910, but hesitated to publish anything, as I desired to keep them under observation. My original plants came from the holding the late Edward King, who had four trees. Five additional plants (from the same locality) were obtained from the late Rev. W. W. Watts in September, 1916.

$\mathrm{Mr}$. Boorman reports that during his exploration of the more coastal areas of the Island, he met with several additional instances of hybrid Howeas, more particularly at the north end of the Island in the vicinity of the rifle-range; also on property oceupied by a Mr. Campbell Stevens, and by Mr. Thompson adjacent. They all appeared to be of the same character as those on Deep Creek to the south-west of the Island, already referred to.

I contrasted the hybrids in 1916 with $H$. Belmoreana and $H$. Forsteriana as follows:-

1. H. Belmoreana.

2. H. Forsteriana.

3. Hybrid.

(a) Leaf segments con- (a) Drooping. verging upwards.

(b) Fruit spikes elongated (individual).

(c) Fruits plump, produced into a shortly truncate apex. (b) Fruit spikes shorter than those of $\mathrm{H}$. Belmoreana (clustered at the base, from 3 to 8 .)

(c) Longer and narrower than those of $\mathrm{H}$. Belmoreana, the truncate apex not produced. (a) and (b) Leaf segments and fruiting spikes as in H. Belmoreana, and its fruits barely separable from that species. The midrib of the leaf has the leaflets (segments) converging upwards, but not quite so eurly as $H$. Belmoreana.

(c) Colour of fruits dull earmine lake (Plate 106, shade 4), with a base of cherry red (Dauthenay's Répertoire de Couleurs, Plate 91, shade 3 ).

Mr. E. N. Ward (18th August, 1920) reports on these hybrid Howeas as follows :-

"They are very variable in size, habit and colour of stem. Five are still in pots in the small bush house. The five planted out in November, 1916 have grown well; two of these are in the palm bed in section 9 in the Lower Garden, one in bed 25 near the Keteleeria japonica tree, and one in bed 20 in the Middle Garden. The other is on the western side of the creek, Upper Garden.

Of the four planted eleven months later, only one is alive and that is doing badly in bed A, lawn 22, Lower Garden. These were planted on low lying ground, very wet in winter, and while these conditions suit some palms they did not suit these hybrids."

The following introduced plants eollected by Mr. Boorman appear to be new records :- 
Compositae.-Ageratum conyzoides L. (Garden escape); Galinsoga parviflora Cav.; Aster subulatus Miehx.; Eupatorium cannabinum L.

Cruciferae.-Sisymbrium officinale L.

LABIATAE.-Stachys arvensis L.

Solanaceae.-Datura Stramonium L.; Nicotiana alata Link and Otto (Garden escape).

UMbelliferae.-Daucus brachiatus Sieb.

LILIACEAE.-Asparagus plumosus var. nanus Baker (Garden eseape). (Not in flower or fruit, and therefore subject to confirmation. Its tough stems point it out as likely to become a pest.)

GraminfaE.-Dactyloctenium aegyptiacum Willd. 


\section{$2 \mathrm{BHL}$ Biodiversity Heritage Library}

Maiden, J. H. 1921. "A few notes on the botany of Lord Howe Island." Proceedings of the Linnean Society of New South Wales 45, 564-566. https://doi.org/10.5962/bhl.part.19562.

View This Item Online: https://www.biodiversitylibrary.org/item/24141

DOI: https://doi.org/10.5962/bhl.part.19562

Permalink: https://www.biodiversitylibrary.org/partpdf/19562

\section{Holding Institution}

MBLWHOI Library

\section{Sponsored by}

MBLWHOI Library

\section{Copyright \& Reuse}

Copyright Status: NOT_IN_COPYRIGHT

This document was created from content at the Biodiversity Heritage Library, the world's largest open access digital library for biodiversity literature and archives. Visit BHL at https://www.biodiversitylibrary.org. 